\title{
Influence of trawling activity on the breeding ecology of a threatened seabird, Audouin's gull Larus audouinii
}

\author{
Daniel Oro ${ }^{1, *}$, Lluis Jover ${ }^{2}$, Xavier Ruiz ${ }^{1}$ \\ 'Departament de Biologia Animal, Vertebrats, Universitat de Barcelona, Diagonal 645, E-08028 Barcelona, Spain \\ ${ }^{2}$ Departament de Salut Pública i LS, Bioestadística, Universitat de Barcelona, Diagonal s/n, E-08028 Barcelona, Spain
}

\begin{abstract}
The influence of a trawling moratorium on the breeding ecology of Audouin's gulls (Larus audouinii Payraudeau) was investigated during 1992 and 1993 in the largest colony of the species in the world (70\% of total population), at the Ebro Delta, NE Spain, western Mediterranean. In this colony, Audouin's gull behaves partly as a scavenger following the trawling fleet and exploiting fishing discards. Each year, the trawling moratorium affected different breeding stages of the species: in 1992 it overlapped with pre-laying and laying stages, while in 1993 it affected most of the chick-rearing stage. We examined differences in laying dates, laying interval, clutch and egg sizes, nest desertion during laying, hatching success, hatchling mass and condition, growth rates, chick survival and breeding success. The moratorium greatly affected egg production in 1992, delaying the start of laying and dramatically decreasing clutch and egg sizes. Intraclutch egg size variation between the 2 years suggests that egg size profiles are outcomes of the interaction between physiological and environmental factors rather than the result of ultimate factors. Nest desertion was much higher in 1992, probably because some females were under a critical body condition threshold and they deserted after laying the first egg. Hatching success also decreased significantly during 1992, probably related to changes in the size and the quality of the eggs. Chick growth and survivorship was higher in 1992, when trawler discards were normally available, than in 1993. Trawler discard availability during chick rearing was more important than egg size in determining chick survival. However, differences were not always significant, since in 1993 the moratorium did not start until the chicks were 1 wk old, and, further, chicks had higher skeletal size and body condition (in order of importance) than in 1992. In fact, chicks had similar fledgling condition in both years at the end of the rearing stage. In 1993, the overall breeding success decreased by $48 \%$. Nevertheless, gulls' breeding performance for the 2 years was much lower than before the establishment of the furst moratorum in 1991, and the situation suggests that clupeords, the prey on which Audouin's gull feed, are scarce. It seems that gulls were not able to compensate for the lack of trawler discards during egg production, since the availabulity of secondary feeding resources was much lower in March and April (pre-laying and laying stages) than in June (chick-rearing stage). Although in long-lived species a decrease in food supply should affect fecundity before affecting adult survival, results confirm the importance of the trawler fleet activity for the conservation of this threatened species.
\end{abstract}

KEY WORDS: Ebro Delta Laridae Fisheries Seabirds Discards Food shortage Western Mediterranean $\cdot$ Reproduction

\section{INTRODUCTION}

The relationship between commercial fisheries and seabirds has attracted much recent attention (e.g. Furness 1982, Nettleship et al. 1984, Croxall 1987). In

•E-mail: daniel@porthos.bio.ub.es some cases, fisheries are thought to compete with seabird communities for fish stocks (Furness 1982, Monaghan 1992 and references therein). In other cases fisheries are considered to favour growth of seabird populations through the exploitation of offal and discarded fish from fishing boats, which has been recorded especially in northern Europe (e.g. Hudson \& 
Furness 1988, Furness et al. 1992, Garthe \& Hüppop 1994). However, Bailey \& Hislop (1978) stated that it was impossible to find any unequivocal proof that offal discarded by fisheries had been the major factor in the increase of any seabird population. Nevertheless, in the Ebro Delta area, NE Spain (western Mediterranean), where the trawling fishing fleet has upheld a yearly moratorium of 2 mo since 1991, confirmation has been provided of the importance of trawler discard availability for the reproductive performance of some seabirds breeding there, such the yellow-legged gull Larus cachinnans or the lesser black-backed gull $L$. fuscus (Oro et al. 1995a, Oro 1996a respectively). The trawling moratorium also overlaps with the Audouin's gull breeding season, though it starts on different dates and hence affects different reproductive stages each year The main effect of this moratorium period is a short food supply for many seabird species breeding there (Oro et al. 1995b, Ruiz et al. 1996), which causes a decrease in breeding parameters (Paterson et al. 1992. Oro et al. 1995a, 1996)

Audouin's gull is one of the few endemic seabirds of the Mediterranean region. Just $15 \mathrm{yr}$ ago its population was estimated to be very small, and threatened (Cramp \& Simmons 1985). However, in 1981 a new colony was established in the Ebro Delta, and since then the colony has grown dramatically to become the largest in the world, comprising more than 10000 pairs in 1994 (about $70 \%$ of total world population) (Pedrocchi \& Ruiz 1995). This increase has been attributed to the exploitation of discards from the local trawler fleet (Oro \& Martínez-Vilalta 1992, Ruiz et al. 1996).

The influence of food supply on the breeding performance of seabirds has been extensively examined in recent years, in both natural (e.g. Monaghan et al. 1992, Hamer et al. 1993, Uttley et al. 1994) and experimental conditions (e.g Hiom et al. 1991, Bolton et al. 1992, 1993). As emphasised by Bolton et al. (1992), some reports on feeding experiments failed to state whether breeding performance of control birds in the year of study is typical for the species. In contrast, studies in natural conditions are hard to carry out because of the great difficulty in manipulating marine food supplies experimentally (Monaghan et al. 1992). In the Ebro Delta, the establishment of a trawling moratorium has allowed us to compare 2 situations with great differences in food availability, since: (1) the diet of Audouin's gull contains a high proportion of trawler discards; and (2) local fishery data demonstrate marked recent reductions in clupeoid availability. Thus, this can be viewed as a natural experiment of dramatic reduction of food availability for the whole colony. Although the axiom the poorer the feeding situation the higher the frequency of parental failure' (Hario 1990) is essentially true, the different results on seabird response recorded in natural experiments suggest that parental capacity to overcome a situation of low food availability seems to depend on the species (Baird 1990, Hamer et al. 1993) and/or the magnitude of the change (Martin 1987). Moreover, differences in food availability may occur within the same breeding season (Murphy et al. 1984, Oro \& Martínez-Vilalta 1994a, Oro et al. 1995a), and intraspecific differences can even be found depending on the colony and its ecological features (Hunt et al. 1986, Oro et al. 1996).

Although previous studies have dealt with the effects of the trawling moratorium on the breeding success of other seabird species breeding here (Oro et al. 1995a, Oro 1996a), the present study includes the effects of this moratorium on other breeding parameters, such as egg-size variability, laying interval, hatching success and chick growth, through comparisons between 2 breeding seasons (1992/1993). In 1992 the moratorium started at the pre-laying and laying stages, while in 1993 the moratorium started later, overlapping with most of the chick-rearing stage (Fig. 1). Moreover, while the studies above did not consider the differences among individuals, the present work deals with marked pairs, which provide a 'pair response' to the moratorium. This study also makes it possible to compare the responses of 3 seabird species to a situation of low food availability; those of the yellow-legged gull. (considered an opportunistic and dominant species; Oro et al. 1995a), Audouin's gull (considered a nocturnal specialist in catching clupeoids, present study), and the lesser black-backed gull (a species ecologically between the above two; Oro 1996a).

\section{METHODS}

Study site. The study was carried out during 1992 and 1993 in the Punta de la Banya $\left(40^{\circ} 37^{\prime} \mathrm{N}, 00^{\circ} 35^{\prime} \mathrm{E}\right.$, Ebro Delta Natural Park, NE Spain), a sandy flat peninsula of 2500 ha with a patchily distributed mosaic of brackish marsh and small dunes covered by halophilous vegetation.

Egg production. Breeding phenology: To determine the start of the laying period, each year a linear transect was established through 2 previously known main subcolony areas. In order to obtain data as accurate as possible on egg production in this species, where nest predation by yellow-legged gulls is low but can occur (Oro \& Martinez-Vilalta 1994a), transects were visited each day in the early morning to establish date of first egg laying, until no new nests were found. Differences between years were tested using the Mann-Whitney test.

Clutch size and laying interval: To determine clutch size, nest contents from 35 and 69 nests in the linear transect were monitored in 1992 and 1993 respectively 
to avoid the bias caused by nest predation (Oro \& Martínez-Vilalta 1994a). To detect differences in clutch size between years, contingency tables and the G-test statistic were used.

To determine the laying interval, the same nests were used 35 and 69 nests in 1992 and 1993 respectively) to record the laying dates. Following the beginning of laying, the nests were observed each day to check for new eggs. Differences between years were tested using the Mann-Whitney test, for both 2- and 3egg clutches.

Egg size variability: On the day of laying, each egg was measured with callipers (length and maximum width to $\pm 0.1 \mathrm{~mm}$ ) and marked according to laying sequence with indelible ink. Egg size was assessed using egg volume estimated through Hoyt's (1979) equation:

Egg volume $\left(\mathrm{cm}^{3}\right)=0.000467 \times$ length $(\mathrm{mm}) \times$ width $^{2}(\mathrm{~mm})$

Only clutches of 2 and 3 eggs were considered, being the modal clutch sizes in 1992 and 1993 respectively. The first step in the analysis was to assess the relevance of the female effect on egg size variability using a 1-way ANOVA for random effect separately for each combination of year and clutch size (2-and 3-egg clutches). To test the effects of year and clutch size we carried out a 2-factor ANOVA on the average volume of the eggs in a clutch. Clutches with known laying order were used to analyze intra-clutch egg size variability. For clutches of 3 eggs we transformed original data to differences between first and second eggs and between second and third eggs. These differences were assessed through their confidence interval and the variability between years was assessed using the $t$ test. The equivalent procedure was used with 2-egg clutches.

Hatching success, chick-hatching size, growth and survival. A wire fence enclosure surrounding some nests was used each year to record the number of chicks fledged per pair (17 nests in 1992, 40 nests in 1993). Fence enclosures have been widely used for recording reproductive success of seabird nesting on the ground (e.g. Bolton et al. 1992, Monaghan et al. 1992), although some effects (negatives or positives) on the final results are expected (see review in Erwin \& Custer 1982). However, the resulting bias using this method may be considered the same in both years, since the number of visits to the enclosures were similar in 1992 and 1993. Nests were also searched once a day for hatched eggs until no new hatchlings were recorded. To detect differences in hatching success, contingency tables and the Fisher Exact Test were used.
Chicks were measured every $3 \mathrm{~d}$ and chick growth between years was also compared. To detect differences in breeding and fledging success between years, contingency tables and the $\chi^{2}$ statistic were used. To check for the difference between years in the slope relating chick body mass and age, an ANCOVA analysis was carried out. To ensure the independence of observations, only 1 mass measure per chick was used, selected randomly from the measurements available in the linear segment of the growth curve (chicks aged between 15 and $30 \mathrm{~d}$ ). Chick condition at hatch was calculated using regression to control for differences in body size, following procedures of Bolton (1991). Hatchling mass ( $\mathrm{n}=31$ chicks in 1992, $n=106$ chicks in 1993) was regressed on tarsus length, and the residuals, expressed as a proportion of the predicted value, were used as a measure of chick condition.

Underlying assumptions of the statistical tests have been verified in all cases.

\section{RESULTS}

\section{Egg production}

\section{Breeding phenology}

When the trawling moratorium overlapped with the pre-laying and laying stages (1992), laying dates were 3 wk later than those of 1993. Median date of start of laying was significantly later in 1992 (13 May) than in 1993 (26 April) (Mann-Whitney U-test $=0.0, p<0.0001$; $\mathrm{n}=61$ in 1992 and $\mathrm{n}=77$ in 1993) (Fig. 2). Moreover, the start of laying was more synchronous in 1993 (Inter Quartile Range < 2 d) than in 1992 (IQR > 5 d) (Fig. 2)

\section{Clutch size and laying interval}

Modal clutch size was low in 1992 (2 eggs), while it was normal in 1993 (3 eggs) (Fig. 3). The Likelihood ratio test shows that frequency distributions were sig-

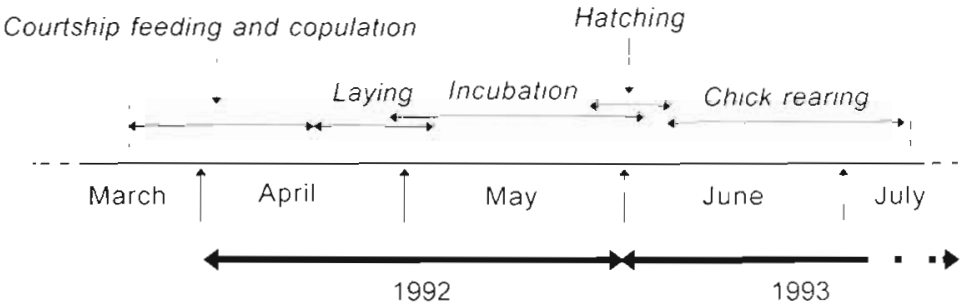

Fig. 1 Graphic representation of Audouin's gull breeding phenology in the Ebro Delta, NE Spain, with normal fishing activities. Solid lines show the extent of the trawling moratorum in 1992 and 1993 


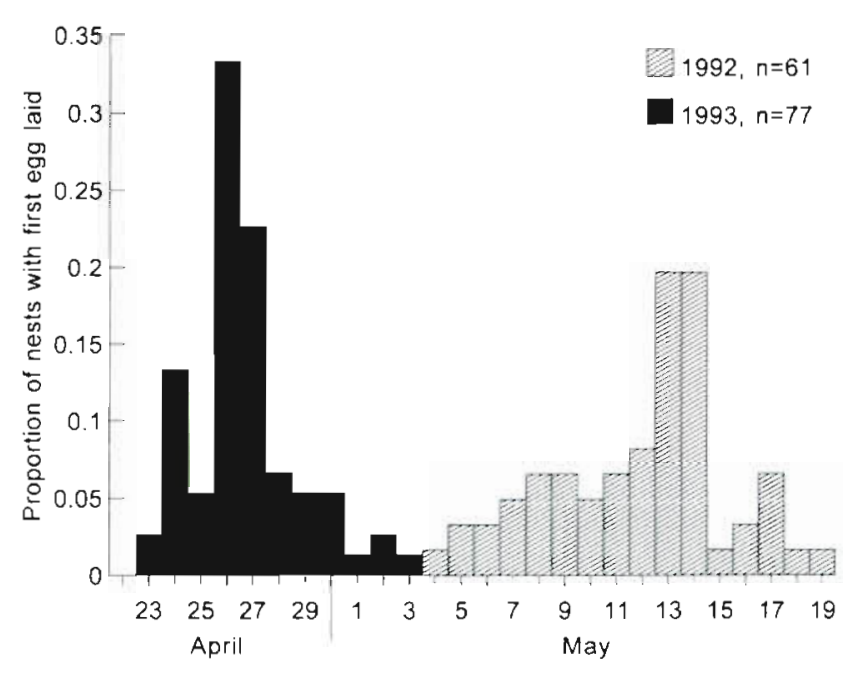

Fig. 2. Proportion of nests of Audouin's gulls with first egg laid in 1992 and 1993 on the Ebro Delta

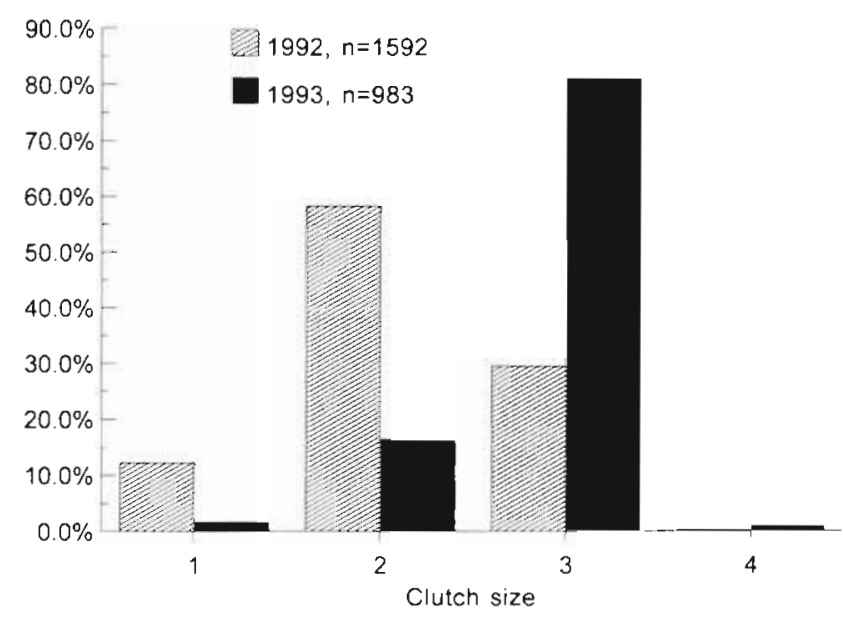

Fig. 3. Percentage of clutch sizes produced by Audouin's gulls on the Ebro Delta in 1992 and 1993

nificantly different between years ( $G$-test $=716, \mathrm{df}=$ 3. $\mathrm{p}<0.0001$ ) (Fig. 3). Looking at the standardized residuals, this difference was mainly attributable to the proportions of 2 - and 3 -egg clutches, although differences in the proportion of 1 -egg clutches were also present.

Clutches laid when trawler discards were not available (1992) tended to have larger laying intervals than those when trawlers operated (1993), but this difference was not significant ( $U$-test $=408.5, p=0.30)$. However, trawler discard availability greatly affected the nest desertion during laying, which was significantly higher in 1992 than in 1993 ( $F$ exact test, p < $0.001)$.
Table 1. Descriptive statistics of average egg volume for Audouin's gulls in a clutch by year and clutch size. Laying order was known for all eggs in the clutch

\begin{tabular}{|ccccc|}
\hline Year & $\begin{array}{c}\text { Clutch } \\
\text { size }\end{array}$ & \multicolumn{3}{c}{ Egg volume $\left(\mathrm{cm}^{3}\right)$} \\
& & Mean & SD & $\mathrm{n}$ \\
\hline 1992 & 2 & 55.78 & 3.60 & 24 \\
& 3 & 55.38 & 2.74 & 20 \\
& Total & 55.30 & 3.21 & 44 \\
1993 & 2 & 57.15 & 4.78 & 5 \\
& 3 & 58.53 & 2.86 & 65 \\
& Total & 58.43 & 3.01 & 70 \\
& 2 & 56.01 & 3.77 & 29 \\
& 3 & 57.79 & 3.12 & 85 \\
& Total & 57.34 & 3.37 & 114 \\
& & & & \\
\hline
\end{tabular}

Egg size variability

A total of 113 eggs from 46 clutches in 1992 (25 2-egg and 213 -egg clutches) and 205 eggs from 70 clutches in 1993 (5 2-egg and 653 -egg clutches) were monitored for egg size variability. As expected, a significant female effect was found from each combination of year and clutch size, except in 1993 for 2-egg clutches because of the low power of the test (only 5 clutches). Thus, clutch size and year effects were evaluated analyzing the average volume of eggs in a clutch (descriptives are shown in Table 1). A significant year effect was found $(F=15.5, \mathrm{df}=1, \mathrm{p}<0.0001)$, while neither clutch size nor interaction between year and clutch size effects was significant $(F=0.03, \mathrm{df}=1, \mathrm{p}>0.5$ and $F=1.07, \mathrm{df}=1, \mathrm{p}>0.3$ respectively).

When the trawling moratorium overlapped with the laying stage (1992), all the eggs in 3-egg clutches were, on average, smaller than their counterparts in 1993 when trawler activity continued, and largest differences were between first eggs (Fig. 4). Differences in profile variation of egg size, attending to laying order, were also noticeable (Fig. 4), i.e. when trawler discards were not available, the second egg was larger than first although the difference was not significant, while in 1993 the first egg was significantly larger than the second. In both years, the third egg was significantly smaller than the second (Fig. 4).

\section{Hatching success}

Trawler discard availability largely affected the hatching success of the clutches laid by Audouin's gulls in the Ebro Delta. Hatching success was significantly higher in 1993 (discards normally available) than in 1992 (discards not available) (Table 2), and it decreased by nearly 10\% in 1992 . 

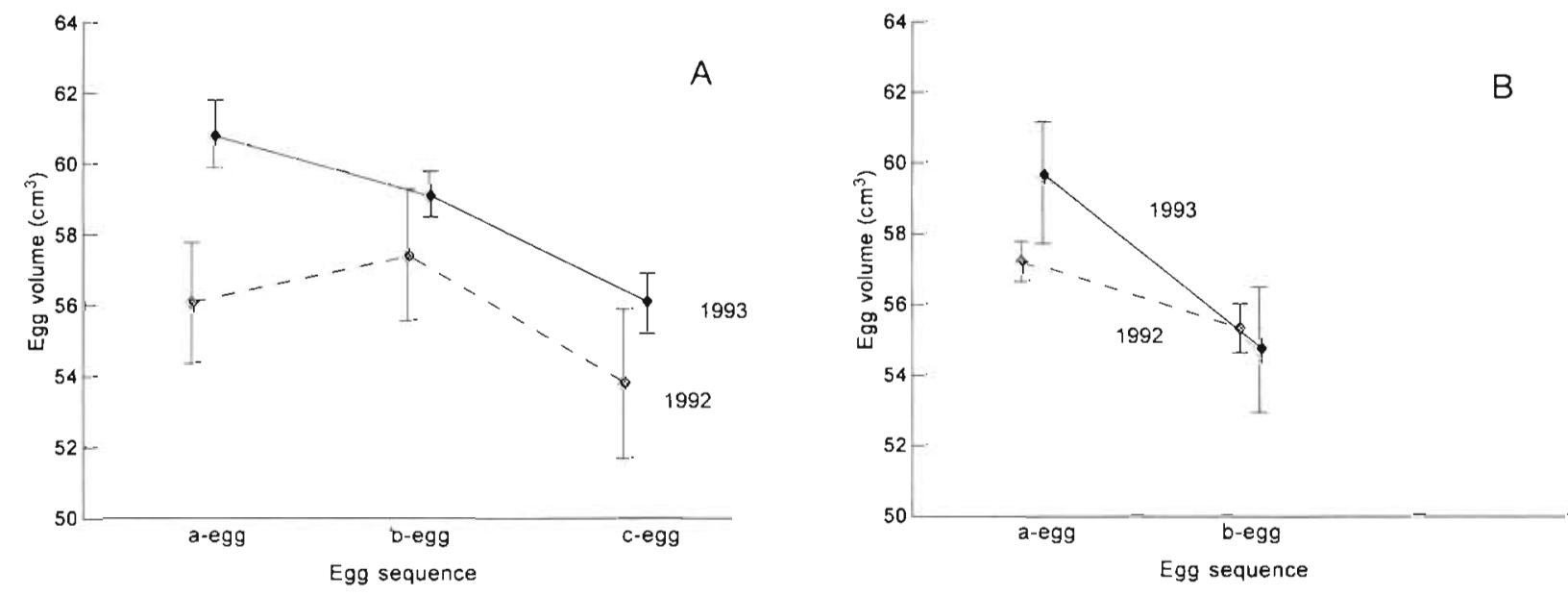

Fig. 4. Mean volume $\left(\mathrm{cm}^{3}{ }_{ \pm} \mathrm{SE}\right)$ of eggs from (A) 3-egg and (B) 2-egg clutches laid by Audouin's gulls on the Ebro Delta in 1992 (trawling moratorium overlapping with laying stage) and 1993 (trawling moratorium overlapping with chick-rearing stage)

\section{Chick size, growth and survival}

Chick hatching size, mass and condition

Table 2 shows that the chicks which hatched from eggs produced by gulls when trawler discards were normally available (1993) were initially larger skeletally and significantly heavier than those from eggs produced when the trawling moratorium overlapped with the laying stage (1992), although this moratorium did not affect the whole hatching stage of either year (Fig. 1). Nevertheless, the differences were only significant in relation to hatchling mass (Table 2), suggest- ing that larger eggs produced heavier chicks, especially because they were skeletally bigger, rather than carrying greater yolk reserves.

\section{Chick growth and survival}

During the chick-rearing stage, the moratorium affected almost the whole chick growth period in 1993 , while it did not overlap chick growth in 1992 (Fig. 1). The data presented in Figs. 5 \& 6 show that chicks of the same age were not heavier in 1992 than those in 1993. Chick condition throughout the growing period

Table 2. Some breeding data for Audouin's gulls on the Ebro Delta, NE Spain, in 1992 and 1993, related to egg production, hatching success, chick size, growth and survival. Eggs lost during incubation due to predation were excluded

\begin{tabular}{|c|c|c|c|c|c|}
\hline Factor affected by moratorium & $\begin{array}{c}1992 \\
\text { ( } \mathrm{n}=17 \text { nests) } \\
\text { Pre-laying }\end{array}$ & $\begin{array}{l}1993 \\
\text { ( } \mathrm{n}=40 \text { nests) } \\
\text { Chick growth }\end{array}$ & Test value & $\mathrm{df}$ & $\mathrm{p}$ \\
\hline Hatching success ( $\%$ ) & 79.5 & 91.4 & Fexact & - & 0.03 \\
\hline $\begin{array}{l}\text { Hatchling mass, } \bar{x} \pm \mathrm{SD} \\
\text { (n) }\end{array}$ & $\begin{array}{c}45.1 \pm 7.2 \\
(31)\end{array}$ & $\begin{array}{l}49.2 \pm 4.4 \\
(106)\end{array}$ & $t=-3.9$ & 135 & $<0.001$ \\
\hline Hatchling condition, $\bar{x} \pm \mathrm{SD}$ & $-1.31 \pm 5.86$ & $0.38 \pm 4.34$ & $t=-1.8$ & 135 & 0.08 \\
\hline $\begin{array}{l}\text { Fledgling condition, } \bar{x} \pm \mathrm{SD} \\
\qquad(\mathrm{n})\end{array}$ & $\begin{array}{c}26.5 \pm 43.3 \\
\{10\}\end{array}$ & $\begin{array}{c}-15.2 \pm 61.5 \\
(1.7)\end{array}$ & $t=1.7$ & 25 & 0.11 \\
\hline Fledging success ${ }^{a}(\%)$ & 32.2 & 16.0 & $\chi^{2}=4.59$ & 1 & 0.03 \\
\hline Breeding success ${ }^{b}(\%)$ & 25 & 13.8 & $\chi^{2}=2.93$ & 1 & 0.09 \\
\hline Mean no. of chicks fledged per nest & 0.58 & 0.42 & - & - & - \\
\hline Total nest failures ${ }^{c}(\%)$ & 58.8 & 67.5 & $\chi^{2}=0.39$ & 1 & 0.53 \\
\hline $\begin{array}{l}\text { Average age at death (d) } \\
\text { (range) }\end{array}$ & $\left(0.5^{7}-19\right)$ & $\begin{array}{c}11 \\
(0.5-37)\end{array}$ & $U=552.0$ & - & 0.003 \\
\hline \multicolumn{6}{|c|}{$\begin{array}{l}\text { "No. of chicks fledged, as a percentage of eggs hatched } \\
\text { "No. of chicks fledged, as a percentage of eggs laid } \\
\text { "Percentage of nests with nil breeding success }\end{array}$} \\
\hline
\end{tabular}


seemed higher in 1992, but growth rates were not significantly different between years (in all cases $p>0.051$. Fledgling condition was also higher in 1992, although differences between years were again not significant (Table 2). In 1993, chick survival decreased after the start of the moratorium (Fig. 7), though chicks died significantly younger in 1992 than in 1993 (Table 2). Fledging success in 1993 was significantly lower than that recorded in 1992, but when clutch size and hatching success were taken into account, there were no significant differences in breeding success between the 2 years. In 1993, total nest failures were higher than in 1992, although this difference was not significant (Table 2), suggesting that although overall breeding success dropped by $48 \%$ in 1993; a few pairs had a high breeding success and they were able to rear more than 1 chick.

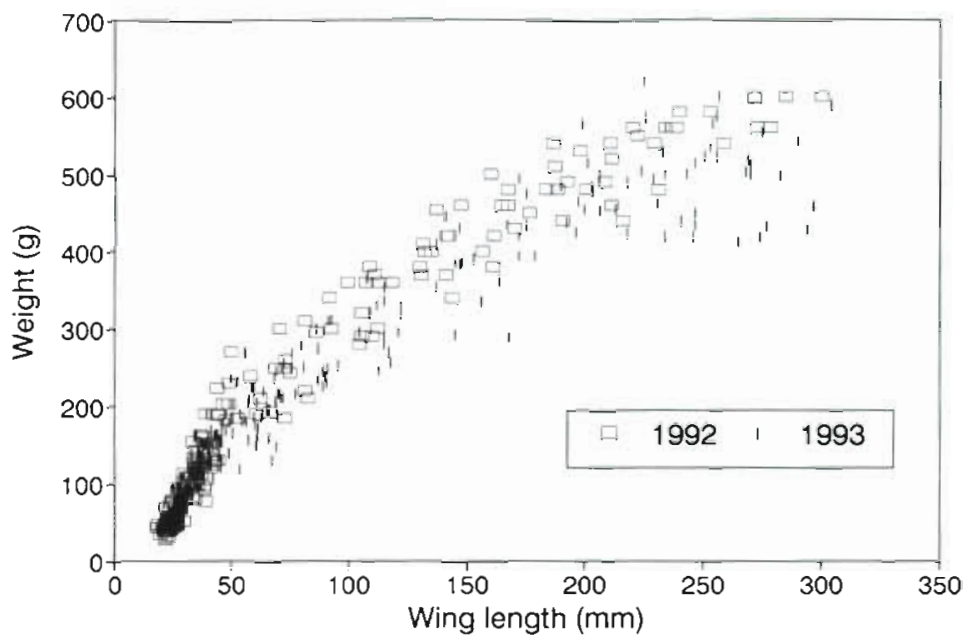

Fig. 5. Weight and wing-length relationships for Audouin's gull chicks in the Ebro Delta in 1992 and 1993, including all the chicks measured up to death or fledging age ( $n=31$ in 1992, $n=106$ in 1993)

\section{DISCUSSION}

\section{Effects of the trawling moratorium on egg production}

In the Ebro Delta, all the parameters of Audouin's gull related to egg production indicated that in 1992 food constraints occurred during egg formation. That year, the start of the trawling moratorium during the pre-laying and laying stages generated a short food supply. The prolonged laying period recorded suggests that in 1992 it was indeed more difficult for

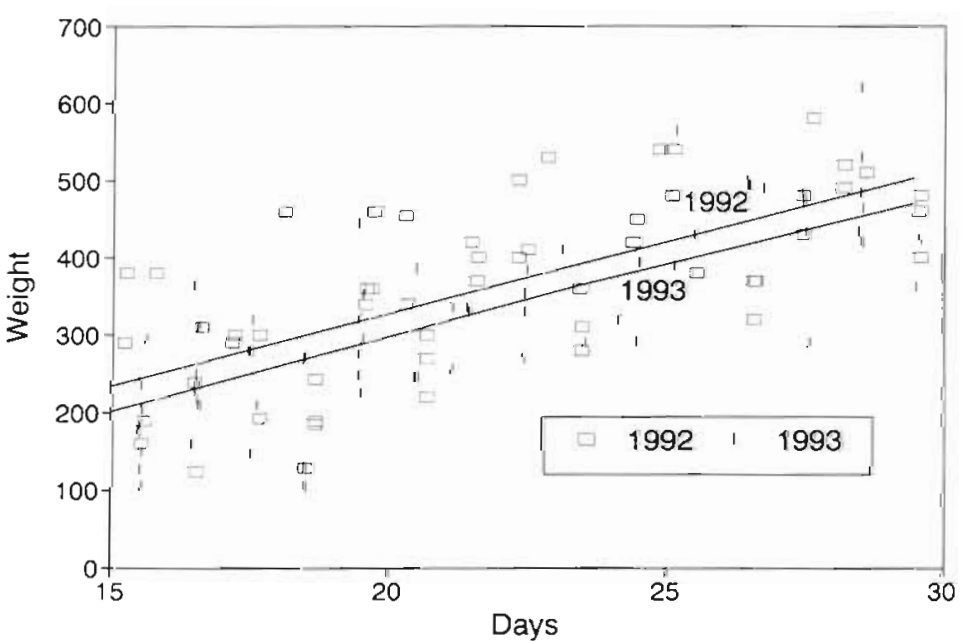

Fig. 6 . Increase of mass with age for Audouin's gull chicks in the Ebro Delta in 1992 and 1993, including all the chicks measured with ages between 15 and $30 \mathrm{~d}(1992: \mathrm{r}=0.428, \mathrm{n}=36, \mathrm{p}<0.05 ; y=19.17 x-86.21$; 1993: $\mathrm{r}=0.651, \mathrm{n}=80, \mathrm{p}<0.05 ; y=18.51 x-43.39$; there was no signif icant difference between the 2 years in the slope of the relationship between mass and age (from 15 to $30 \mathrm{~d}$ old): ANCOVA $F=1.739, \mathrm{df}=1$, $p>0.05$ females to acquire the reserves necessary for egg formation (Pierotti \& Bellrose 1986). The effects of the trawling moratorium on egg size in 1992 were also consistent responses to nutritional constraints during egg formation (Walsberg 1983. Hatchwell \& Pellatt 1990, Bolton et al. 1992). Furthermore, the large differences in intraclutch egg size variation between years suggest that egg size differences are outcomes of the interaction between physiological and environmental factors (Pierotti \& Bellrose 1986, Bolton et al. 1992). The differences recorded in the profiles between 1992 and 1993 show that the variability in first egg volume was larger than in second and/or third egg, suggesting differences in specific nutrients in egg production between years (Bolton et al. 1992). Moreover, if egg size is reduced before clutch size when resources for egg formation are limited (Martin 1987, Bolton 1991), the exceptionally low clutch size also recorded in 1992 suggests not just a situation of food shortage, but dramatic low food availability for the gulls during the pre-laying stage.

On the other hand, although there is an inverse relationship between clutch size and laying dates in gulls (Davis \& Dunn 1976. authors' unpubl. data), it is unlikely that the delay recorded in breeding phenology of Audouin's gulls in the Ebro Delta in 1992 explains the large differences in egg production, either in egg or clutch sizes. Other studies in seabirds have similarly recorded that the laying date was sensitive to food supply, i.e. it was delayed when food availability was 


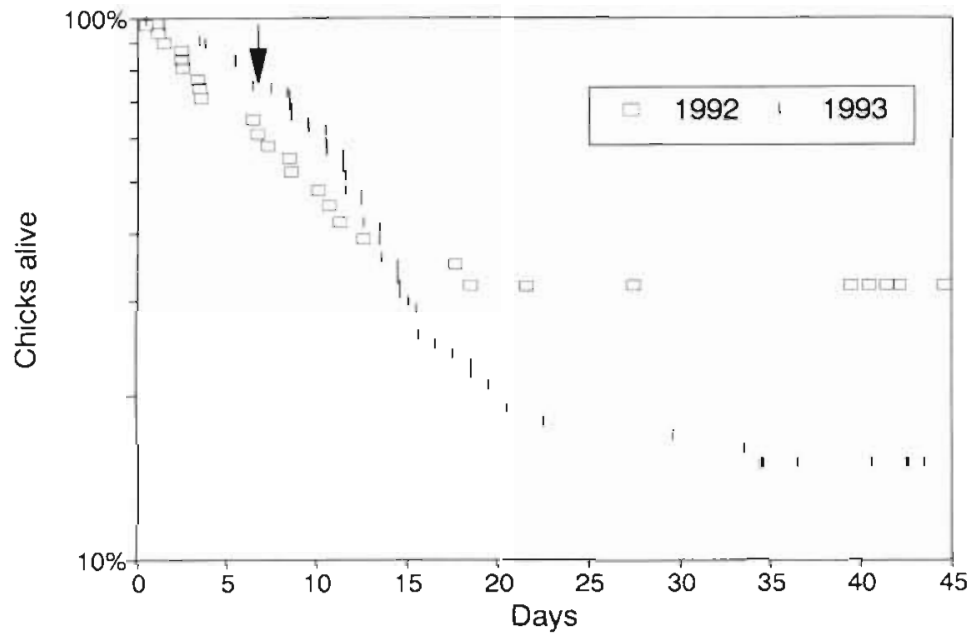

Fig. 7. Age of Audouin's gull chicks alive plotted on a logarithmic scale against survivorshup percentage. Arrow shows the start of the trawling moratorium in 1993 in relation to the median hatching date. Significant differences were found in the pattern of chick mortality between the

2 years (Kolmogorov-Smirnov 2 -sample test $=1.754, \mathrm{p}<0.005$ ) depend on the importance of the change in the food supply (Martin 1987).

\section{Effects of trawler discard availability on chick size, growth and survival}

The lack of trawler discard availability during pre-laying of Audouin's gull in 1992 had a great effect on chick size, especially on its mass. This variation in chick mass may be the direct result of variation in egg size, which is especially related to parental quality (Bolton 1991, Bolton et al. 1992). Thus, hatchling chicks of Audouin's gulls were skeletally larger and heavier in 1993 than in 1992, when adult body condition was probably much better as a result of normal trawler discard availability.

However, the situation after hatching reversed in relation to pre-laying and laying stages, and in 1992 discards were available

low (Safina et al. 1988, Monaghan et al. 1989, Uttley et al. 1994). As Bolton et al. (1992) showed for lesser black-backed gulls, food supply affected clutch size independently of time of laying, probably due to the level of the pre-laying female body reserves (Houston et al. 1983, Hario et al. 1991, Bolton et al. 1993). In contrast, when trawler discards were not available, laying intervals increased only slightly. This suggests that laying interval is less sensitive to fluctuations in food supply, in contrast to that supposed by Lack (1968) or Murton \& Westwood (1977), who strongly correlated food supply with typical bird laying interval. As Astheimer \& Grau (1985) stated, rapid yolk deposition (RYD), timing and lag period are very conservative processes, and they are relatively unaffected by environmental conditions. At the same time, nest desertion during laying was much higher in 1992, probably because some females were below a critical fitness threshold and they deserted after laying the first egg (Monaghan et al. 1992).

Hatching success was significantly lower in 1992 than 1993, probably due to changes in the size and the quality of the eggs (Coulson \& Thomas 1985. Bolton et al. 1992), and also to changes in incubating attendance or predation rates (Morris 1987, Hébert \& Barclay 1988, Pons 1992, Oro \& Martínez-Vilalta 1994a). Nevertheless, although similar studies found the same effect in hatching success when food was in short supply (Baird 1990, Pons 1992), most of them have recorded no effect on hatching success in poor years (e.g. Monaghan et al. 1989, Hamer et al. 1991, 1993, Uttley et al. 1994). Effects on hatching success are likely to vary between species and they probably during chick rearing, which allowed the gulls to feed their nestlings normally. Moreover, the trawling moratorium in 1993 did not start until chicks were on average 1 wk old, cancelling, only partly, the advantages of being heavier (Bolton 1991, Uttley et al. 1994. Amundsen 1995). Thus, direct comparisons of chick survival and growth between the 2 years are difficult to make. Most of the differences in chick growth and survival recorded between years were not significant, probably because: first, hatching chick mass was higher in 1993 since eggs were much larger that year and they probably had greater growth and survivorship (Parsons 1970, Nisbet 1978, Hatchwell \& Pellat 1990, but see Bolton 1991); second, because the first week of chick rearing in 1993 was not affected by the trawling moratorium, probably increasing their subsequent survival that year (Bolton 1991); and third, gulls might mitigate the lack of trawler discards by increasing nocturnal activity (Oro 1995, Oro et al. 1995b) and/or the foraging range (following trawler fleet beyond the moratorium range, i.e. more than $100 \mathrm{~km}$ from the colony; Arcos \& Oro 1996), exchanging discards for prey from rice fields, such as the American crayfish Procambarus clarckii or the aquatic beetle Hydrous pistaceus (Oro et al. 1995b, Ruiz et al. 1996), or diversifying their foraging strategies (showing kleptoparasitic behaviour both interspecific and intraspecific: Oro \& Martinez-Vilalta 1994a, Oro 1996b). The results further indicate that Audouin's gull fledgling chicks had growth rates very similar between years, and they may grow at just above a threshold rate under which they normally died. In fact, the chick fledging condition was very similar in both years. The reversed timing of the trawl- 
ing moratorium during chick growth, i.e. the moratorium overlapped mainly with laying and incubation in 1992 and mainly with chick rearing in 1993, may also be a proximate determinant of the lack of differences in growth rates. This is in contrast to the results obtained by Monaghan et al. (1989) on Arctic terns or by Uttley et al. (1994) on guillemots, who recorded significantly lower chick growth rates when food availability was low.

However, it is still unknown how the difference in chick condition at the fledging stage between the 2 years might affect future survivorship and recruitment probability, which are normally constrained by fledgling body condition (Spear et al. 1995). Moreover, if survival of young to age 1 yr seems to provide a more reliable estimate of recruitment probability and of a parent's reproductive success (Spear \& Nur 1994), breeding success in 1993 was probably overestimated, since that year the trawling moratorium extended after the fledging dates.

The present study has assessed the differences in reproductive performance of the species between 2 years when low food availability occurred in different breeding stages. Thus, these 2 mo moratoria have allowed us to study not only an experimental situation of food shortage affecting the whole colony, but also to assess the breeding performance of Audouin's gulls depending on the breeding stage affected. Basically, the trawling moratorium affected egg production in 1992 and chick rearing in 1993. Therefore, the reproductive success in both years may have been greatly affected, especially when compared with those recorded before the start of the trawling moratorium in 1991 (Oro \& Martínez-Vilalta 1992). However, the reproductive success was not nil either in 1992 or in 1993, probably also because the trawling moratorium never affected the whole breeding season of the species, unlike other studies which recorded total or dramatic breeding decreases during periods of low food availability (Monaghan et al. 1989, 1992, Pons 1992. see also Oro et al. 1996 for an example of total breeding failure in Audouin's gulls).

Most of the studies dealing with the relationship between the breeding ecology of seabirds and food availability recorded marked decreases in breeding and fledging success, while effects on egg production were not pronounced (e.g Hamer et al. 1991, 1993, Monaghan et al. 1992), probably because chick rearing is the period with the highest energy demand during the breeding season. In the Ebro Delta, the estimated bioenergetic model of the Audouin's gull colony also shows that chick rearing is the most energetically costly stage, $13 \%$ more than egg production (Ruiz et al. 1994). The effects of the trawling moratorium in the Ebro Delta were as remarkable in fledging success as in those studies, but egg production was also largely affected. Trawler discards represent for Audouin's gull up to $70 \%$ by biomass of its diet (Ruiz et al. 1994, 1996). Most of the parameters related to egg production were affected, but only fledging success was significantly lower in 1993, while differences in chick growth, fledgling condition, fledging success and total nest failures were small. When the trawler discards are not available, the gulls may compensate for the lack of this main resource by exploiting alternative foraging resources or by increasing the foraging range. Although little is known about long-term changes in clupeoid density in the Mediterranean, it seems that fish catches in the Mediterranean have decreased more than $20 \%$ in the last $20 \mathrm{yr}$, as a result of overfishing and pollution (Safina 1995). Although clupeoids, especially sardine Sardina pilchardus, are the main prey of Audouin's gulls (Ruiz et al. 1996), during trawling moratorium periods alternative proy came partly from the rice fields, also suggesting that clupeoid density may have decreased in recent years and is insufficient to maintain the feeding requirements of the colony. Gulls also performed opportunistic foraging strategies, such as interspecific kleptoparasitism on smaller seabird species (Oro 1996b). Nevertheless, there are great differences in the availability of these secondary feeding resources for the species in this colony between March-April (pre-laying and laying stages) and May-June (chick-rearing stage). The differences related to foraging in the rice fields resulted from the hydrological cycle of the rice culture, since fields are not flooded until the end of April, and the availability of rice field prey increases especially after June (González-Solís et al. 1996). Kleptoparasitic hosts are also only available during chick rearing, since all the smaller seabird species arrive to breed at the colony in May. Thus, when the trawling moratorium overlapped with the laying stage (1992), gulls were probably under their buffering capacity because of the lack of alternative prey and foraging strategies, as happens in the Audouin's gull colony of the Columbretes Islands, an area also affected by the trawling moratorium, where total breeding failure has been recorded over some years (Oro et al. 1996). Moreover, the increase in foraging range was probably limited during pre-laying because of sperm competition (Salzer \& Larkin 1990).

Reproduction was probably more costly in 1993 than in 1992 because the moratorium overlapped with the most energetically costly breeding stage (Ruiz et al. 1994), and also because the number of chicks hatched per nest was much lower in 1992 (low clutch size combined with low hatching success). The overall breeding success indeed declined by $48 \%$, very similar to declines recorded by Pons (1992), when changes in a 
refuse tip caused a large decrease in refuse availability. This decline was also very similar to those recorded for the yellow-legged gull in the Ebro Delta as a result of the moratorium (Oro et al. 1995a), but much higher than those recorded for the lesser black-backed gull (more than $80 \%$; Oro 1996a). Different strategies to compensate for the decrease in trawler discard supply are probably not available for the lesser black-backed gull, such as nocturnal clupeoid catching (used by Audouin's gull; Ruiz et al. 1996) or use of refuse tips (used by yellow-legged gulls; Oro et al. 1995). Before the establishment of the moratorium, the high food availability around the Ebro Delta colony of Audouin's gull (trawler discards, clupeoid densities, accessory or secondary foraging resources) probably allowed the highest breeding success ever recorded for the species. However, this high breeding success cannot by itself explain the dramatic population growth of this colony. A high adult immigration rate occurring at least during the first years may explain this growth (Ruiz et al. 1994). Immigration was probably made up of nonbreeding adults who, up to the establishment of this colony, were unable to find a suitable place to breed. In fact, the low number of suitable breeding places and their small surface areas are some of the most important limiting factors for and threats to the species. The Audouin's gull colony has increased since the establishment of the moratorium, but since 1994 its growth has seemed to be declining (Oro et al. 1996). This is probably due to the lower recruitment rate of birds born in the first years affected by the moratorium, since Audouin's gulls start to breed when they are 3 yr old (Oro \& Martínez-Vilalta 1994b, Ruiz et al. 1994).

The trawling moratorium has affected breeding performance in the last few years, suggesting that gulls are now suffering greater long-term costs of reproduction, probably affecting both adult survival and recruitment rates (Reid 1987, Jacobsen et al. 1995). However, the decrease in food availability would not necessarily have to be followed by a significant decrease in adult survival (Pons \& Migot 1995). As predicted by life-history theory, in a long-lived species such as Audouin's gull, a decrease in food supply should affect fecundity before affecting adult survival (Birkhead \& Furness 1985, Pons \& Migot 1995). Nevertheless, this Audouin's gull colony may be threatened if the trawling moratorium is continued for many years, as is currently being negotiated.

Acknowledgements. We are very grateful to Xell Genovart, Albert Bertolero, Vittorio Pedrocchi, Milagros González, and Eduardo Mateos for their help with the field work; to Robin Rycroft for improving the English text, and to Mark Bolton for his valuable comments on the manuscript and his support. We also thank Albert Martínez and all the head staff of the P.N. del Delta de l'Ebre for their help and support, and to Isabel Palomera and Rogelio Abad for their comments on fishery research. Research funds were provided by the P.N. del Delta de l'Ebre, Servei the Protecció i Gestió de la Fauna (Generalitat de Catalunya), the DGICYT grant PB91-0271 of the Spanish Government and the Instituto para la Conservación de la Naturaleza ICONA. The Audouin's Gull Project is sponsored by Iberia Líneas Aéreas Españolas

\section{LITERATURE CITED}

Amundsen T (1995) Egg size and early nestling growth in the snow petrel. Condor 97:345-351

Arcos JM, Oro D (1996) Changes in foraging range of Audouin's gull Larus audouinii in relation to a trawling moratorium in the western Mediterranean. Colon Waterbirds 19 (in press)

Astheimer LB, Grau CR (1985) The timing and energetic consequences of egg formation in the Adélie penguin. Condor $87: 256-268$

Bailey RS, Hislop JRG (1978) The effects of fisheries on seabirds in the northeast Atlantic. Ibis 120:104-105

Baird PH (1990) Influence of abiotic factors and prey distribution on diet and reproductive success of three seabird species in Alaska. Ornis Scand 21:224-235

Birkhead TR, Furness RW (1985) Regulation of seabird populations. In: Sibly RM, Smith RH (eds) Behavioural ecology. Blackwell, Oxford, p 147-168

Bolton M (1991) Determinants of chick survival in the lesser black-backed gull: relative contributions of egg size and parental quality. J Anim Ecol 60:949-960

Bolton M, Houston D, Monaghan P (1992) Nutritional constraits on egg formation in the lesser black-backed gull: an experimental study. J Anim Ecol 61:521 - 532

Bolton M, Monaghan P. Houston DC (1993) Proximate determination of clutch size in lesser black-backed gulls: the roles of food supply and body condition. Can J Zool 71 $273-279$

Coulson JC, Thomas CS (1985) Changes in the biology of the kittiwake Rissa tridactyla: a 31-year study of a breeding colony. J Anim Ecol 54:9-26

Cramp S, Simmons KL (1985) The birds of western Paleartic, Vol. Ill. Oxford University Press, Oxford

Croxall JP (1987) Seabirds: feeding ecology and role in marine ecosystems. Cambridge University Press, Cambridge

Davis JWF, Dunn EK (1976) Intraspecific predation and colonial breeding in lesser black-backed gulls Larus fuscus Ibis 118:65-77

Erwin RM, Custer TW (1982) Estimating reproductive success in colonial waterbirds: an evaluation. Colon Waterbirds 5 : 49-56

Furness RW (1982) Competition between fisheries and seabird communities. Adv Mar Biol 20:225-302

Furness RW, Ensor K, Hudson AV (1992) The use of fishery waste by gull populations around the British Isles. Ardea $80: 105-113$

Garthe S, Huppop O (1994) Distribution of ship-following seabirds and their utilization of discards in the North Sea in summer. Mar Ecol Prog Ser 106:1-9

González-Solís J, Bernadí X, Ruiz X (1996) Seasonal variation of waterbird prey in the Ebro Delta rice fields. In: Crivelli AJ, Hafner H, Fasola M, Erwin RM, McCrimmon DA Jr (eds) Ecology, conservation and management of colonial waterbirds in the Mediterranean region. Colon Waterbirds 19 Spec Publ 1:135-142 
Hamer KC, Furness RW, Caldow RWG (1991) The effects of changes in food availability on the breeding ecology of great skuas Catharacta skua. J Zool 223:175-188

Hamer KC, Monaghan P, Uttley JD, Walton P. Burns MD (1993) The influnnce of food supply on the breeding ecology of kittiwakes Rissa tridactyla in Shetland. Ibis 135: $255-263$

Hario M (1990) Breeding fallure and feeding conditions of lesser black-backed gulls Larus $f$. fuscus in the Gulf of Finland. Ornis Fenn 67:1.13-129

Hario M, Kilpi M. Selin K (1991) Parental investment by the sexes in the herring gull: the use of energy reserves during early breeding. Ornis Scand 22:308-312

Hatchwell BJ, Pellat J (1990) Intraspecific variation in egg composition and yolk formation in the common gullemo (Uria aalge). J Zool 220:279-286

Hébert PN, Barclay RMR (1988) Parental investment in her rng gulls: clutch apportionment and chick survival. Condor $90: 332-338$

Hiom L, Bolton M, Monaghan P, Worrall D (1991) Experimental evidence for food limitation of egg production in gulls Ornis Scand 22:94-97

Houston DC, Jones PJ, Sibly RM (1983) The effect of female body condition on egg laying in lesser black-backed gulls Larus fuscus. J Zool 200:509-520

Hoyt DF (1979) Practical methods of estimating volume and fresh weight of bird eggs. Auk $96: 73-77$

Hudson AV, Furness RW (1988) Utilization of discarded fish by scavenging seabirds behind whitefish trawlers in Shetland. J Zool 215:151-166

Hunt GL, Eppley ZA, Schneider DC (1986) Reproductive performance of seabirds: the importance of population and colony size. Auk 103:306-317

Jacobsen KO, Erikstad KE, Saether BE (1995) An experimental study of the costs of reproduction in the kittiwake Rissa tridactyla. Ecology 76:1636-1642

Lack D (1968) Ecological adaptations for breeding in birds Chapman and Hall, London

Martin TE (1987) Food as a limit on breeding birds: a lifehistory perspective. Annu Rev Ecol Syst 18:453-487

Monaghan P (1992) Seabirds and sandeels: the conflict between exploitation and conservation in the northern North Sea Biodivers Conserv 1:98-111

Monaghan P, Uttley JD, Burns MD (1.992) Effect of changes in food availability on reproductive effort in Arctic terns Sterna paradisea. Ardea 80:71-81

Monaghan P, Uttley JD, Burns MD, Thaine C, Blackwood J (1989) The relationship between food supply, reproductive effort and breeding success in Arctic terns Sterna paradisea. J Anim Ecol 58:261-274

Morris RD (1987) Time-partitioning of clutch and brood care activities in herring gulls: a measure of parental quality? Stud Avian Biol 10:68-74

Murphey EC, Day RH, Oakley KL, Hoover AA (1984) Dietary changes and poor reproductive performance in glacouswinged gulls. Auk 101:532-541

Murton RK. Westwood NJ (1977) Avian breeding cycles. Clarendon Press, Oxford

Nettleship DN, Sanger GA, Springer PF (1984) Marine birds: their feeding ecology and commercial fisheries relationships. Canadian Wildlife Service, Ottawa

Nisbet ICT (1978) Dependence of fledging success on egg size, parental performance and egg composition among common and roseate terns, Sterna hirundo and S. dougallii. Ibis 120:207-215

Oro D (1995) The influence of commercial fisheries in daily activity of Audouin's gull Larus audouinii in the Ebro
Delta, NE Spain. Ornis Fenn 72:154-158

Oro D (1996a) Effects of trawler discard avallability on egg laying and breeding success in the lesser black-backed gull Larus fuscus in the western Mediterranean. Mar Ecol Prog Ser 132:43-46

Oro D (1996b) Interspecific kleptoparasitism in Audoun's gull Larus audouinii: a behavioural response to low food availability. Ibis 138:218-221

Oro D, Bosch M, Ruzz X (1995a) Effects of a trawling moratorium on the breeding success of the yellow-legged gull Larus cachinnans. Ibis 137:347-349

Oro D. Genovart X, Ruiz X, Jiménez J, García-Gans J (1996) Differences in diet, population increase and breeding performance between two colonies of Audouin's gulls Larus audouinii affected by a trawling moratorium. J Avi Biol 27 (in press)

Oro D, Martínez-Vilalta A (1992) The colony of Audouin's gull in the Ebro Delta. Avocetta 16:36-39

Oro D. Martínez-Vilalta A (1994a) Factors affecting kleptoparasitism and predation rates upon a colony of Audouin's gull (Larus audoumii) by yellow-legged gulls (Larus cachinnans) in Spain. Colon Waterbırds 17:35-41

Oro D, Martínez-Vilalta A (1994b) Migration and dispersal of Audouin's Gull Larus audouinii from the Ebro Delta. Ostrich 65:225-230

Oro D, Pedrocchi V, González-Solis J (1995b) The effects of fishing activities on the diet of Audouin's quli Larus audouinii in the Ebro Delta, NE Spain. In: Tasker ML (ed) Threats to seabirds: Proceedings of the 5th International Seabird Group conference. Seabird Group, Sandy, UK, p 38-39

Parsons J (1970) Relationship between egg size and post hatching chick mortalıty in the herring gull (Larus argentatus). Nature 228:1221-1222

Paterson AM, Martinez-Vilalta A, Dies JI. (1992) Partial breeding failure of Audouin's Gull in two Spanish colonies in 1991. Br Birds 85:97-100

Pedrocchi V. Ruiz X (1995) On the current status of Audouin's gull Larus audouinii in the Mediterrantian. In: Tasker ML (ed) Threats to seabirds: Proceedings of the 5th International Seabird Group conference Seabird Group, Sandy, UK, p 40

Pierotti R, Bellrose CA (1986) Proximate and ultimate causation of egg size and the 'third-chick disadvantage' in the western gull. Auk 103:401-407

Pons JM (1992) Effects of changes in the avalability of human refuse on breeding parameters in a herring gull Larus argentatus population in Brittany, France. Ardea 80: $143-150$

Pons JM, Migot P (1995) Life-history strategy of the herring gull: changes in survival and fecundity in a population subjected to various feeding conditions. J A nim Ecol 64 $592-599$

Reid WV (1987) The cost of reproduction in the glaucouswinged gull. Oecologia 74:458-467

Ruiz X, Abella JC, de la Fuente $M$, Genovart $M$, GonzálezSolís J, Jover L, Oro D, Pedrocchi V. Roca V, Sanpera C (1994) Ecología y dinámica de la población de la Gar inta de Audouin (Larus audounii). ICONA.-Universitat de Barcelona, Barcelona

Ruiz X, Oro D, Martínez-Vi]alta A, Jover L (1996) The feeding ecology of Audouin's Gull in the Ebro Delta. In: Crivelli AJ, Hafner H, Fasola M, Erwin RM, McCrimmon DA Jr (eds) Ecology, conservation and management of colonial waterbirds in the Mediterranean region. Colon Waterbirds 19 Spec Publ 1:68-74

Safina C (1995) The world's imperiled fish. Sci Am 273:46-53 
Safina C, Burger J, Gochfeld M, Wagner RH (1988) Evidence for prey limitation of common and roseate tern reproduction. Condor 90:852-859

Salzer DW, Larkin GJ (1990) Impact of courtship feeding on clutch and third-egg size in glaucous-winged gulls. Anim Behav 39:1149-1162

Spear L, Nur N (1994) Brood size, hatching order and hatching date: effects on four life-history stages from hatching to recruitment in western gulls. J Anim Ecol 63:283-298

This article was submitted to the editor
Spear $L$, Sydeman WJ, Pyle P (1995) Factors affectung recruitment age and recruitment probability in the western gull Larus occidentals. Ibis 137:352-359

Uttley JD, Walton P, Monaghan P, Austin G (1994) The effects of food abundance on breeding performance and adult time budgets of guillemots Uria aalge. Ibis 136: $205-213$

Walsberg GE (1983) Avian ecological energetics. Avi Biol 7 . $161-220$

Manuscript first received: February 2, 1996

Revised version accepted: April 19, 1996 